INDEPENDENT JOURNAL OF MANAGEMENT \& PRODUCTION (IJM\&P)

http://www.ijmp.jor.br $\quad$ v. 11, n. 5, Special Edition IFLOG 2019 -September 2020 ISSN: 2236-269X

DOI: 10.14807/ijmp.v11i5.1298

\title{
REVERSE LOGISTICS IN SÃO SEBASTIÃO AND ILHABELA HANDMADE BREWERIES: ADVANTAGES AND CHALLENGES
}

\author{
Leonardo Castilho Borges \\ FATEC São Sebastião, Brazil \\ E-mail: leonardo120_5@hotmail.com \\ Victoria Bartuciotti Hipocreme Macedo \\ FATEC São Sebastião, Brazil \\ E-mail:macedo109@gmail.com \\ Orlando José de Souza Celestino \\ FATEC São Sebastião, Brazil \\ E-mail: orlando.celestino@fatec.sp.gov.br
}

Submission: 2/29/2020

Revision: $3 / 2 / 2020$

Accept: 3/6/2020

\section{ABSTRACT}

This article describes the advantages and challenges faced by the handmade beer producers of São Sebastião and Ilhabela regarding the use of reverse logistics in their production processes. It begins with a review of the growing demand of handmade breweries and the need to refine their logistical processes. The following is a referenced description of reverse logistics and how it has become an important competitive differential in the reduction of waste disposal in the environment and its consequent reduction in costs. Analyzing what types and to what extent production control is performed and how the use of reverse logistics is faced, through bibliographic research and case studies. For this purpose, questionnaires were carried out with handmade beer producers and it was possible to conclude which advantages and challenges can be faced by producers in the reverse logistics between them, the advantages in the reduction of costs and the aggregation of socio-environmental value, and the disadvantages such as financial unfeasibility and difficulties in obtaining packaging.

Keywords: reverse logistics; production control; handmade brewer 
DOI: 10.14807/ijmp.v11i5.1298

\section{INTRODUCTION}

The production of handmade beer has been gaining increasing prominence due to the wide variety of styles with various flavors and aromas possible, according to ABRACERVA (2019) (Brazilian Association of Handmade Beer) registered in June 2019 the brewery number one thousand, there were 111 new factories authorized in the first 5 months of 2019.

Analyzing map data from the Ministry of Agriculture, Livestock and Supply from 1999 to 2009, the number of plants increased from 192 to 255, an increase of $32.8 \%$. The big increase happened in the last decade, reaching a thousand breweries, a growth of $292.1 \%$, reports ABRACERVA (2019). Only in 2018, there were 210 new plants: 30.9\% more than the previous year.

According to the president of ABRACERVA (2019), Carlo Lapolli, the largest concentration should follow in the South and Southeast. Ilhabela and São Sebastião, following this growing market, promoted meetings of handmade brewers in the cities. According to the Ilhabela Beer Festival website (2019) the event is held by the Confraria dos Cervejeiros Artesanais de Ilhabela with the support of the City Hall. In São Sebastião the event is promoted by the Associação dos Cervejeiros Artesanais de São Sebastião (ACASS) also with the support of the City Hall.

In the market for handmade beers about $80 \%$ of the products are in glass packaging, a significant result can be obtained since a returnable glass bottle can be reused up to 20 times before disposal according to AMBEV (2019).

Refining their logistical processes shows itself as an advantageous exit for producers, the implementation of reverse logistics for the recovery of packages (glass bottles) after consumption, can be an important competitive differential because it presents itself as a solution in the reduction of production costs and reduction in the disposal of waste in the environment, since the bottles are reinserted in the production cycle, in addition to adding value of socio-environmental responsibility to the brand.

The reverse flow of containers and/or glass recycling contributes to the reduction of production costs, improves the company's image and reduces environmental impacts, states Novaes (2015).

Based on the above facts, this paper aims to describe the reverse logistics of handmade breweries, and demonstrate their advantages and disadvantages from the point of view of producers, and thus enable and assist brewers in the cities of São Sebastião and Ilhabela. 
DOI: 10.14807/ijmp.v11i5.1298

The paper used bibliographic research with emphasis on field studies with local brewers. This leads to the question: what are the advantages and challenges of reverse logistics in the production cycle of handmade beer producers in Ilhabela and São Sebastião?

The specific objectives of this paper are to analyze to what extent the handmade beer producers of Ilhabela and São Sebastião control their logistical processes and to find out what challenges may arise throughout the process of reverse logistics and to perform an analysis of the pros and cons of reverse logistics.

\section{LITERATURE REVIEW}

\subsection{Logistics And Reverse Logistics}

According to Ballou (2006), in 1962 the organization of professionals, managers and educators in the area of logistics was created in order to encourage teaching in this field. This organization, named Council of Logistics Management (CLM), defines logistics as: "The process of planning, implementing and controlling the efficient and effective flow of goods, services and related information from the point of origin to the point of consumption in order to meet customer requirements.

The focus of logistics, for Christopher (2002, p. 10) is "to plan and coordinate all activities necessary to achieve desirable levels of service and quality at the lowest possible cost. For him, logistics should be seen as the link between the market and the company's operational activity, from the management of raw materials to the delivery of the final product.

The Council of Supply Chain Management Professionals (2012) defined logistics as:

Logistics is the process of planning, execution and procedures for the efficient and effective transportation and storage of goods, including services and related information from the point of origin to the point of consumption for the purpose of conforming to customer requirements. This definition includes input, output, internal and external movements.

According to Stock (1998), reverse logistics is located within business logistics, having as main responsibility the return of products, recycling, replacement and reuse of materials, waste disposal and remanufacturing of materials from the reverse logistics process. 


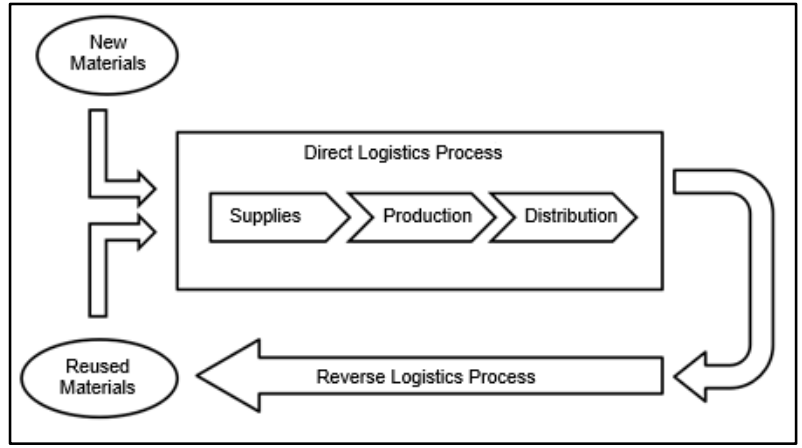

Figure 1: Schematic representation of the direct and reverse logistics process. Source: Adapted from Lacerda (2002)

According to Chaves and Batalha (2006, p.2-3) the concept of reverse logistics in the 1980s was limited only to the reverse movement of the direct flow of products in the supply chain, from the 1990s onwards new concepts emerged due to greater environmental concern, companies began to see logistics as a way of reducing losses.

Novaes (2015) defined reverse logistics as the process that recovers and stores material goods in order to revalue them or allocate them without causing environmental impacts, which according to Lacerda (2000) is a concern demanded by the customers themselves today, however this has become an important factor in improving economic performance since reuse generates cost savings reflected in lower investment in packaging.

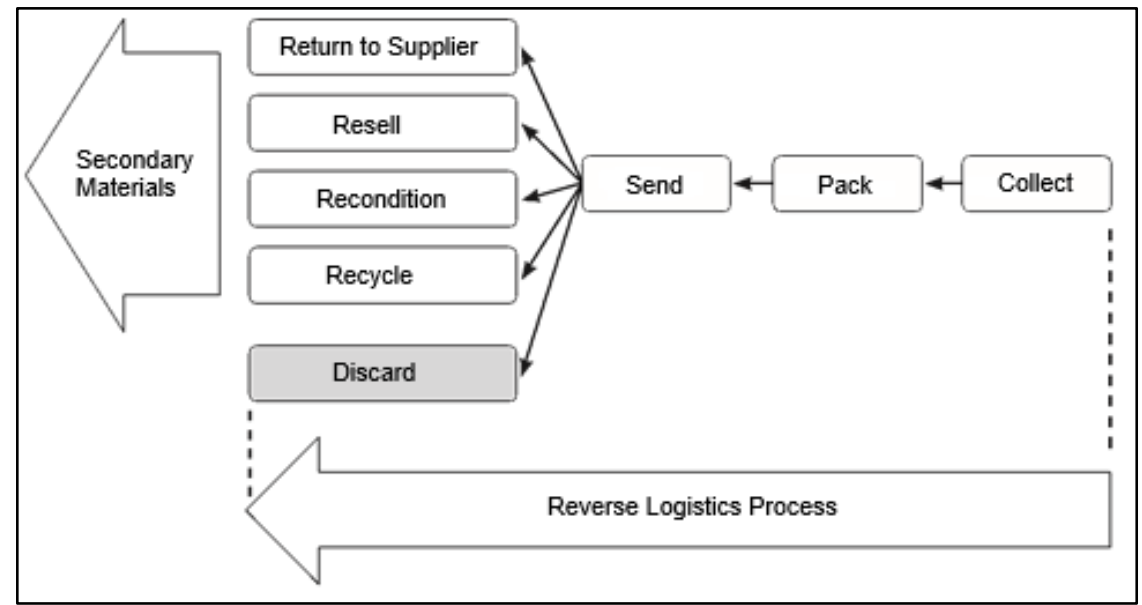

Figure 2: Typical activities of the reverse logistics process.

Source: Adapted from Lacerda (2002)

Leite (2003) states that the return of after-sales or post-consumption goods to the productive cycle of the business adds economical, ecological, corporate image values, among others. The main interest of this paper aims at the reverse logistics of post-consumption products that are constituted by the reverse flow of a part of the materials originated in the disposal of the products after their use by the original user and returning to the productive cycle. 
DOI: 10.14807/ijmp.v11i5.1298

There are two reverse subsystems: the reverse recycling channels and the reverse reuse channels.

According to the Secretary of Environment of the State of São Paulo (2014), the reverse logistics of post-consumption refers to the return of products after use by customers, so that the correct destination is given, preferably reuse and recycling.

In the case of the Waste Policies, the post-consumption residues of the products or their packaging, are returned to the productive cycle for reuse and reuse, as in the case of a returnable beverage bottle, explains the Secretary of Environment of the State of São Paulo (2014).

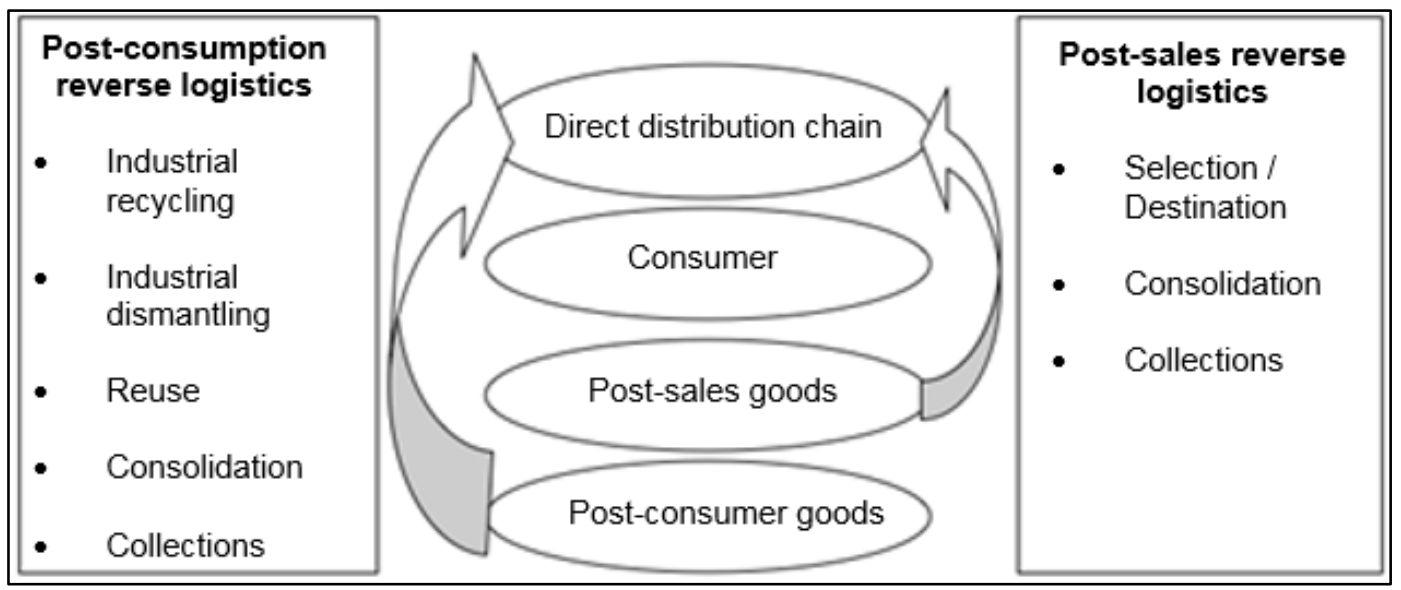

Figure 3: Reverse logistics after sales and after consumption.

Source: Adapted from Leite (2002)

Leite (2009) states that:

The strategic objective is to add value to a logistic product consisting of goods that are unserviceable to the original owner, or that still have conditions of use, products discarded because they have reached the end of their useful life and industrial waste. These post-consumption products may originate from durable or disposable goods and flow through reverse channels of reuse, dismantling, recycling, until their final destination.

Some authors present the advantages and disadvantages of reverse logistics. According to Guarnieri (2014), the possibility of obtaining economic advantages in the reuse of raw materials and feasibility of using returnable packaging.

The website Sua Pesquisa (2015) suggests that reverse logistics can offer cost savings in production processes, since waste or obsolete products feed the production chain, which reduces raw material acquisition costs.

Some improvements in reverse logistics processes can generate considerable financial returns, which justify greater investments in this area, says Lacerda (2009). 
DOI: 10.14807/ijmp.v11i5.1298

On the other hand, Felipe (2009) notes that there is greater need for control to be developed over products. He also states that there is an increase in labor and additional space for storage of returned products.

Ávila and Griebeler (2013) point out that there is a lack of staff and partners prepared to carry out this type of activity and also an increase in material transportation costs.

The authors Adlmaier and Sellitto (2007) attest that the initial investment in reverse logistics is very high, especially when it involves the exchange of packaging and standardization.

Liva, Pontelo and Oliveira (2003) concludes that the quantity of products that returns to the organization is larger than it produces and also that returnable products occupy space in warehouses and deposits, and ends up generating costs.

\title{
2.2. Supply Chain
}

For Ballou (2006, p. 27) logistics and the supply chain comes to be:

\begin{abstract}
A set of functional activities (transportation, stock control, etc.) that are repeated countless times along the channel through which raw materials are being converted into finished products, to which value is added to the consumer. Since the sources of raw materials, factories and points of sale in general do not have the same location and the channel represents a sequence of production stages, logistics activities can be repeated several times until a product reaches the market. Then, logistical activities are repeated as the products used are transformed upstream into the logistical channel.
\end{abstract}

According to Simchi-Levi, Kaminsky and Simchi-Levi (2010) the supply chain, which can also be called a logistics network, consists of suppliers, production center, warehouses, distribution center, retailers, in addition to stocks of raw materials, in-process products and finished products.

Chehebe (1998) explains that ACV (Life Cycle Analysis) researches the interaction between a product and the environment, evaluating environmental aspects and potential impacts associated with the product life cycle.

The ACV of a given product comprises the steps from the removal of the nature of the raw materials in the production system, through all industrial and consumer operations to the disposal of the final product at the end of its useful life (CHEHEBE, 1998).

The life cycle of the product does not end with the delivery of the product to the consumer, reverse logistics is used to close the life cycle of the product that was discarded by the consumer or has become obsolete, according to Ballou (2006). 
DOI: 10.14807/ijmp.v11i5.1298

According to Leite (2002) the production chain is based on input supply, manufacturing, product distribution, sales and reverse logistics, i.e., the return of post-sales and post-consumption goods to the business cycle or the production cycle, through reverse distribution channels, adding value of various kinds: economical, ecological, legal, logistical, corporate image, among others.

\title{
2.3. National Solid Waste Policy
}

In Brazil, the law 12.305 of August 2, 2010 establishing the National Policy for Solid Waste defines that reverse logistics is:

\begin{abstract}
An instrument of economic and social development characterized by a set of actions, procedures and means designed to enable the collection and return of solid waste to the business sector, for reuse, in its cycle or in other production cycles, or other final destination environmentally appropriate (BRAZIL, 2010).
\end{abstract}

According to Mueller (2005), the main reasons for companies to act strongly in Reverse Logistics are: (1) Environmental legislation, which forces companies to return with their products and take care of the necessary treatment; (2) Economical benefits of using products that return to the production process, to the detriment of the high costs of correct garbage disposal; and (3) The growing environmental awareness of consumers.

In accordance with the law 12.305 of August 2, 2010, which defines reuse as the process of using solid waste without its biological, physical or physical-chemical transformation, in compliance with the conditions and standards established by the competent bodies of SISNAMA (National Environmental System) and, if applicable, the SNVS (National Health Surveillance System) and SUASA (Unified Agricultural Health Care System).

\subsection{Social and Environmental Responsibility}

According to Razzolini Filho and Berté (2009); Catallão and Fogolin (2011) socioenvironmental responsibility has become interesting for organizations that in order to maintain a positive image develop organizational strategies, transforming the obligations charged by the government into advantages such as cost reduction and green marketing.

Green marketing, environmental marketing or ecological marketing, is a modality derived from basic marketing which aims to meet the needs of those customers who have a differentiated behavior because they are concerned with sustainable measures and damage to nature. It consists of the application of promotion, production and also the recovery of products that are ecological and sensitive to the environment (BOONE; KURTZ, 2001, p. 71). 
DOI: 10.14807/ijmp.v11i5.1298

New needs have arisen in logistics processes due to the interest in social and environmental responsibility, in Europe there are legal guidelines that support reverse logistics. (ADLMAIER; SELLITTO, 2007, p. 395)

\subsection{Types of Control}

\subsubsection{Cost Control}

The costs must be controlled so that the company can maximize its profit, according to Rocha and Selig (2002) managing to execute and measure adequately concepts and techniques of costs, the company can easily determine objectives, strategies, goals and initiatives allowing an effective management and monitoring of the company.

Hansen and Mowen (2001) claim that cost information is used to identify and develop organisational strategies, and to achieve competitive and sustainable advantages.

\subsubsection{Process Control}

According to Corrêa and Corrêa (2004), process management is concerned with strategically coordinating the scarce resources (human, technological, informational and others), as well as their interaction and the processes they produce, and deliver goods and services focusing on meeting the needs and/or desires of quality, time and cost of their clients.

The problems of not having a production planning and control are big, as Corrêa and Corrêa (2004) highlight loss of sales due to insufficient production capacity, high costs, underutilization of labor, high stocks, inadequate production levels.

However, Slack (1997) explains that it is essential for producers targeting where the organization intends to go in order to guide and give direction to processes and activities, but in order to function effectively they must be planned and controlled, because planning and control are the activities that will assist in deciding how to use the best resources thus ensuring the execution of what has been planned.

\subsection{ERP Systems}

Integrated management systems or ERPs (Enterprise Resource Planning) provide tracking and global visibility of information from any part of the company and its Supply Chain, which enables intelligent decisions, say the authors Chopra and Meindl (2003).

According to Mesquita (2000), ERP systems offer the following advantages for the organization: 
- Greater control of costs, allowing the control of actual expenses and time in each process performed, helping the management of production processes;

- Greater control of the production cycle, which in turn helps the company to manage all stages of production of a service or product;

- The incorporated planning tools, assist in organizational and strategic planning, resulting in an optimization of decision-making processes and;

- Elimination of the use of manual interfaces, enabling internal service processes to be performed digitally, without the need for paper.

\section{METHODOLOGY}

For the development of this article, a bibliographical research of the proposed subject was carried out, through books, monographs, and specialized sites. And together with the bibliographic review, a case study was made with handmade beer producers, where data were observed and collected to be later analyzed and demonstrated in the results obtained.

To find out the advantages and challenges of using reverse logistics in a brewery, a questionnaire with open and closed questions was carried out with 29 producers of handmade beer from Ilhabela and São Sebastião. The data obtained allowed to establish an overview of the current situation of these handmade beer producers, showing to what extent they know and use the reverse logistics of glass packaging in their processes. The data obtained allowed a clear observation of the advantages and challenges of the producers in the practice of bottle reverse logistics.

\section{ANALYSIS OF RESULTS AND DISCUSSION}

\subsection{Production Control}

Through the indicators obtained in the graphs in the research it was possible to obtain an overview of the levels of control used by producers in their production processes, and thus to profile these producers and understand their relationship with reverse logistics.

\subsection{Control Of Production Costs}




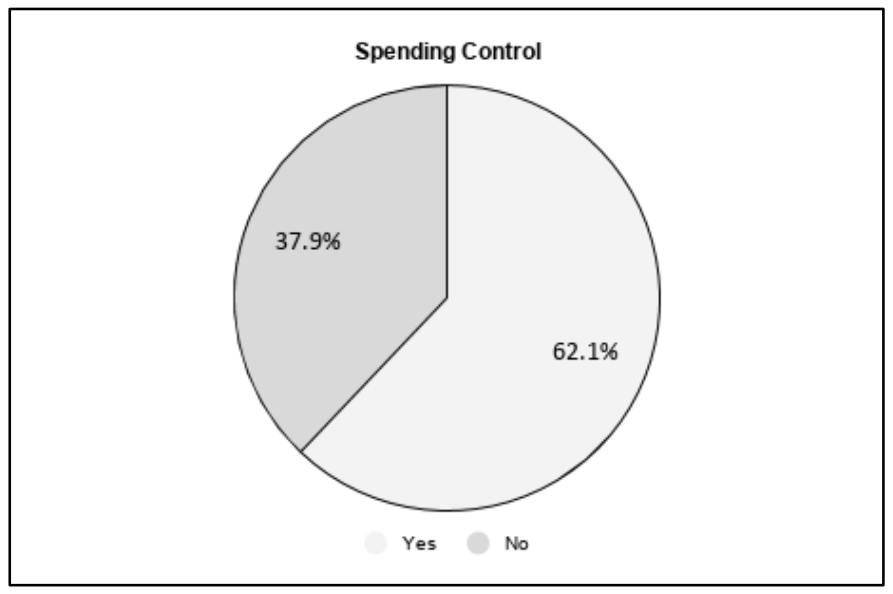

Graph 1: Spending Control

Source: Authors (2019)

According to the survey, 38\% of producers do not control their spending in the cities of Ilhabela and São Sebastião. However, 62\% of the interviewees consider this factor important for the survival of the company in the increasingly competitive market, demonstrated in graph 1. Expenses must be controlled so that the company can maximize its profit. Through the results obtained with the spending control, it is possible to develop strategic actions that favor an effective management, bringing competitiveness to the company (ROCHA; SELIG, 2001; HANSEN; MOWEN, 2001).

\subsection{Type Of Control Used}

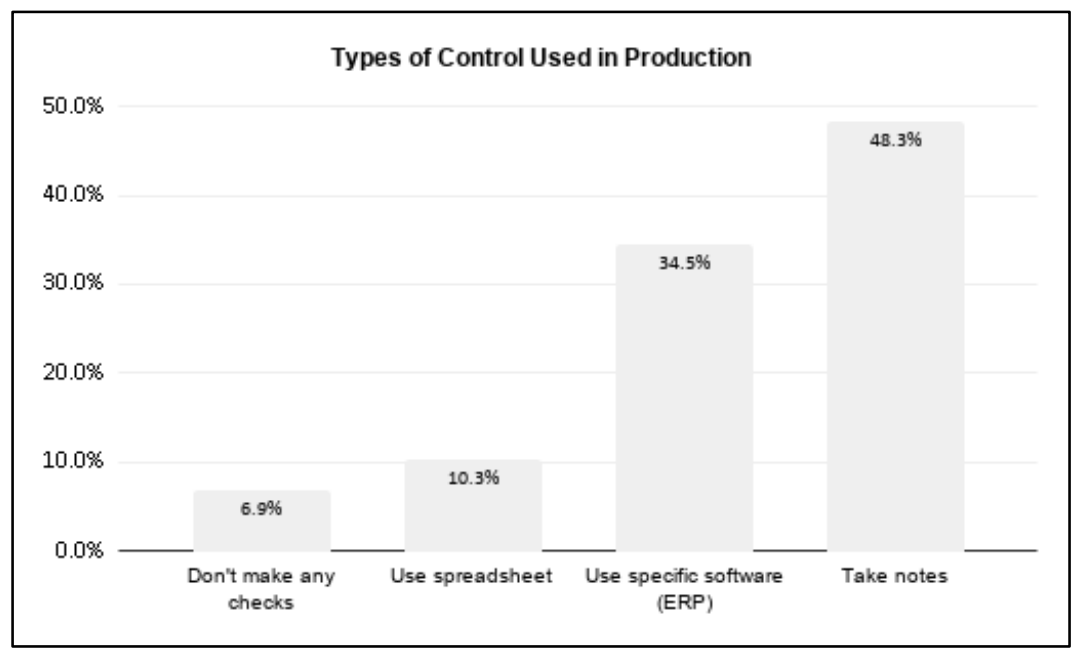

Chart 2: Types of Control Used in Production Source: Authors (2019)

Chart 2 refers to the type of control tool used by brewers in production, the options were; no control, specific software, spreadsheet and notes. Only 35\% of the producers have a software (ERP) for the control, while $48 \%$ end up using precarious methods such as "annotations" which can cause an uncontrollable process, increasing costs and reducing the 
DOI: 10.14807/ijmp.v11i5.1298

company's profit. The 35\% that use specific software, can enjoy certain advantages in the use of systems (ERP) such as greater control of costs and production cycle, improved management of stages, less time spent on processes, better strategies, optimized processes and better decisions (MOSQUE, 2000).

\subsection{Level Of Control Used}

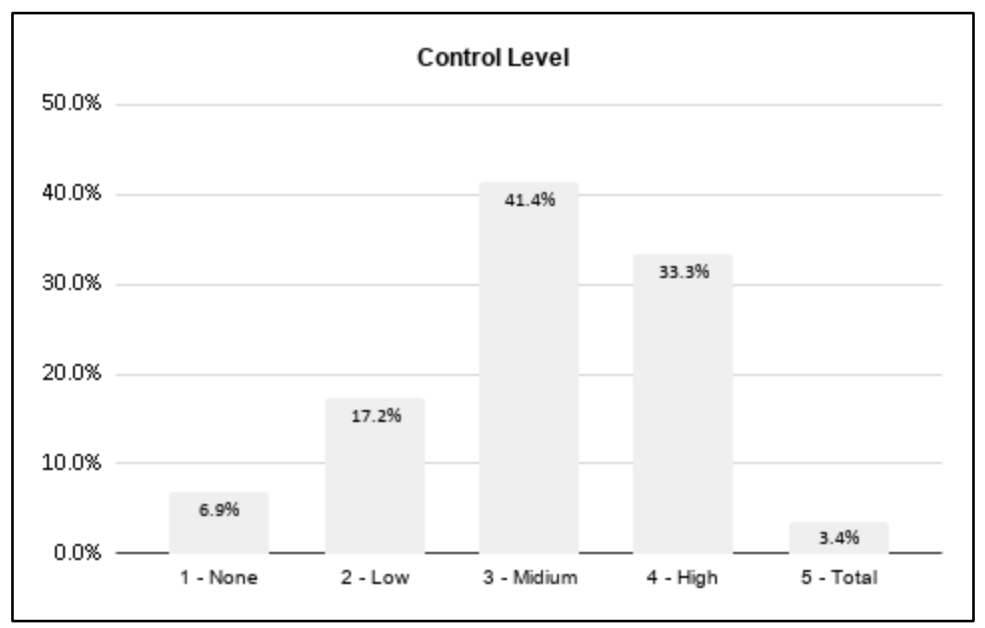

Chart 3: Control Level

Source: Authors (2019)

The questionnaire asked what level of control producers use in their processes, giving a score from 1 to 5, with 1 - None, 2 - Low, 3 - Medium, 4 - High, 5 - Total.

Looking at Chart 3, only 1 of the respondents considers their control to be level 5, that is, a control with total confidence that the entrepreneur can use their data for coherent decision making. In order to achieve this objective, it is necessary to strategically coordinate all resources in view of their interaction with processes and how their results will be delivered to customers (CORRÊA; CORRÊA, 2004).

It is possible to note, however, that the majority of respondents claim to control production processes in a median way, which can incur problems such as incongruous production not meeting or exceeding too much demand, product without standard, consequently losing sales, excess stock, reducing competitiveness. (CORRÊA; CORRÊA, 2004).

\subsection{Percentage Of Packaging Reused In Production}


DOI: 10.14807/ijmp.v11i5.1298

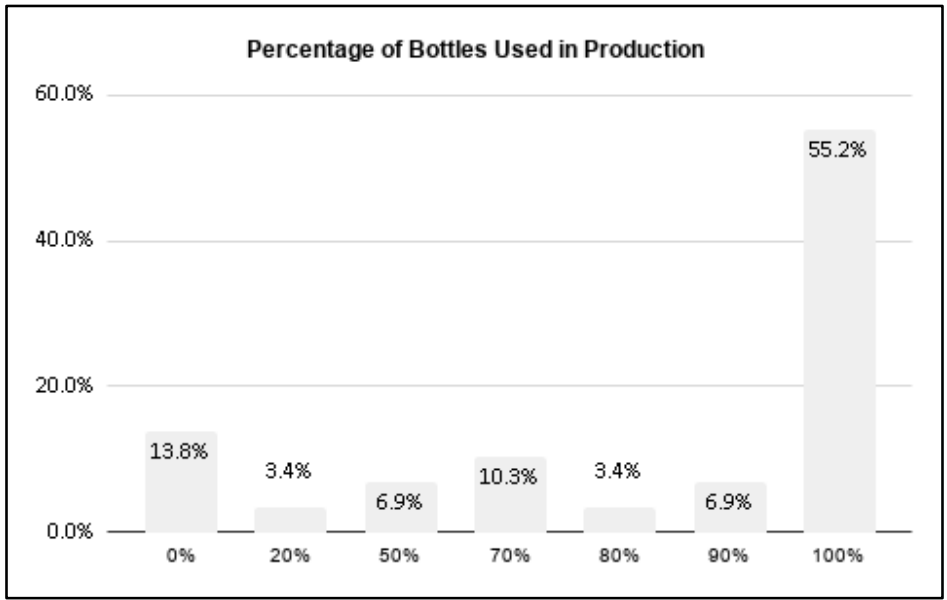

Chart 4: Percentage of Bottles Used in Production Source: Authors (2019)

As highlighted in Chart 4, more than half of the respondents reuse $100 \%$ of their packaging in production, the vast majority are concerned with improving economic performance by reusing packaging in order to reduce costs (LACERDA, 2000). Another strong motivator for reuse is the growing environmental awareness of consumers (MUELLER, 2005).

\subsection{Monthly Production Volume And Degree Of Reuse Of Bottles}

Table 1: Relationship between monthly production volume and degree of bottle reuse

\begin{tabular}{c|c|c|c}
\hline & Total reuse & Partial reuse & No reuse \\
\hline Less than 100 litres & 13 & 6 & 0 \\
\hline Between $\mathbf{1 0 0}$ and 400 litres & 2 & 2 & 1 \\
\hline Between 400 and 700 litres & 1 & 1 & 0 \\
\hline Between 700 and 1000 litres & 0 & 0 & 1 \\
\hline More than 1000 litres & 0 & 0 & 2 \\
\hline
\end{tabular}

Source: Authors (2019)

According to table 1, although most of the interviewees perform reverse logistics in their production, it is noted that producers with higher production capacity prefer not to reuse the bottles, using new bottles or even using anote tope of packaging. For these producers, the degree of complexity and costs of implementing reverse logistics is greater, making the practice of reverse logistics unfeasible. The recurring reason in most cases is financial unfeasibility and lack of knowledge of reverse logistics procedures. (FELIPE, 2009; ADLMAIER; SELLITTO, 2007; LIVA; PONTELO; OLIVEIRA, 2003).

\section{7. $\quad$ Reuse Of Bottles}


DOI: 10.14807/ijmp.v11i5.1298

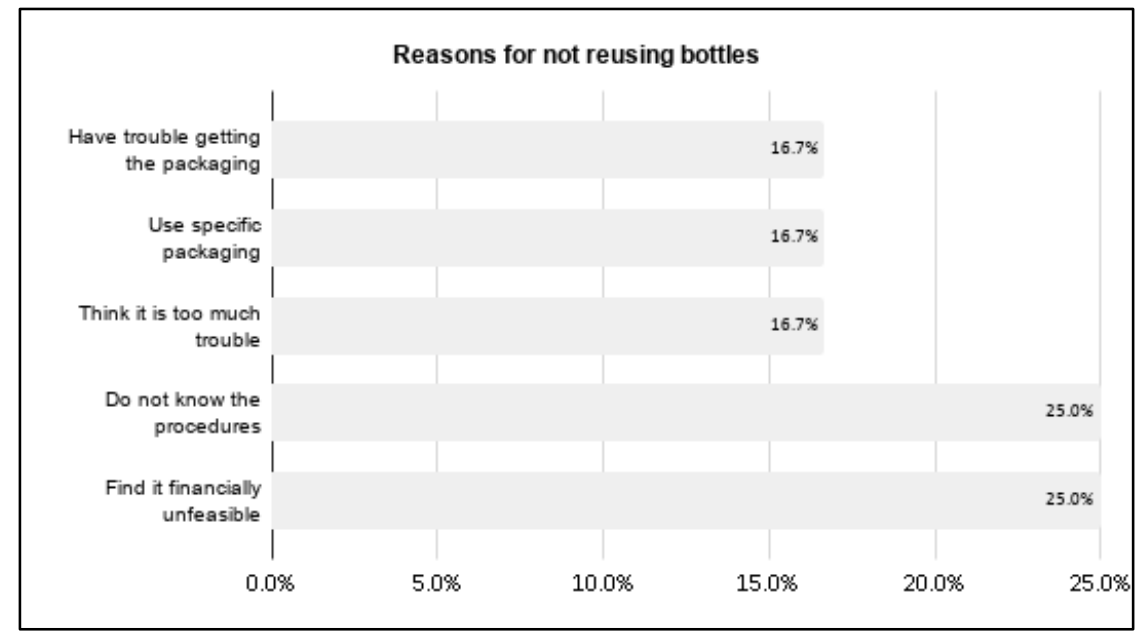

Chart 5: Reasons for not reusing bottles

Source: Authors (2019)

They choose not to use reverse logistics since the initial investment is very high. (ADLMAIER; SELLITTO, 2007). There is a greater need for manpower and additional storage space. (FELIPE, 2009). There is a lack of team and partners prepared to perform this type of activity (ÁVILA; GRIEBELER, 2013).

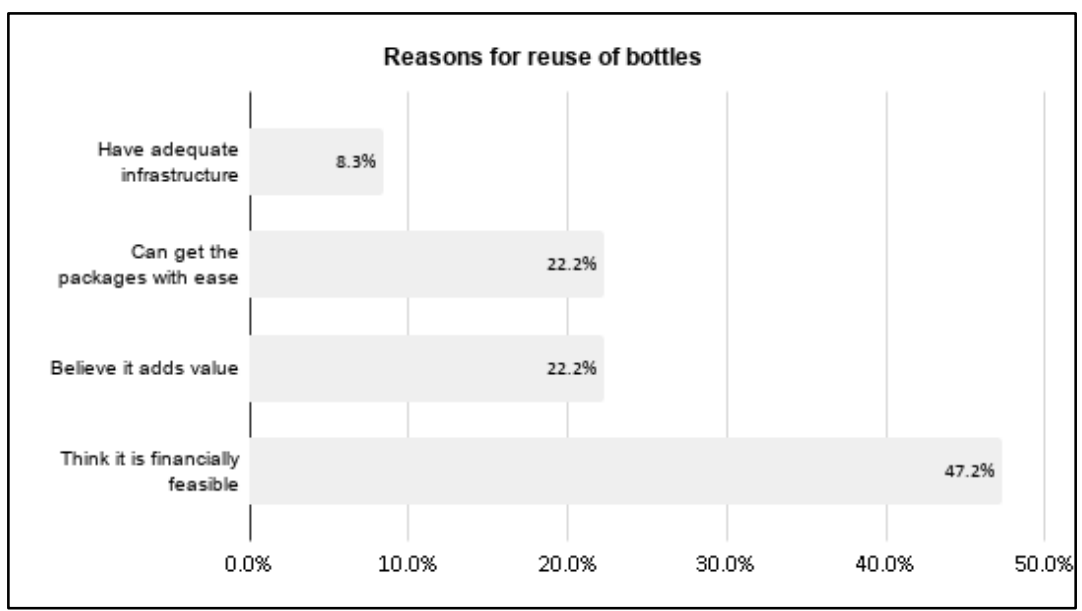

Chart 6: Reasons for reuse of bottles Source: Authors (2019)

It should be noted that $47.2 \%$ of producers who reuse packaging believe it is financially feasible. With the reuse of the bottles it is possible to save on the costs of the production processes and the purchase of raw material (SUA PESQUISA, 2015). The fact that they have a leaner production facilitates the purchase of packaging and does not take up so much storage space.

\section{CONCLUSION}

The research identified that the profile of producers in the city of São Sebastião and Ilhabela in general is quite eclectic, from the point of view of the approach of the processes, 
DOI: 10.14807/ijmp.v11i5.1298

maturity and size of the companies, it was possible to identify two distinct groups among the producers, with particular characteristics allowing to analyze the interaction of these producers with reverse logistics.

The results of the research corroborate the studies obtained by other authors. It is possible to see that the advantages and disadvantages found by producers are common in organizations that intend to implement reverse logistics in their production cycle.

Another factor observed is that the perception of small producers is proportionally inverse to that of large producers regarding the use of reverse logistics.

Small producers (up to 100 litres/month) find advantages in applying reverse logistics, such as ease and low cost in purchasing, reconditioning and reintroducing packaging into production processes.

On the other hand, producers with higher production volume (over 700 litres/month), find difficulties in implementing reverse logistics because the costs of return and storage of packaging are high due to the large amount needed to supply the production, as the complexity of the processes increases with the increase in volume produced. Producers do not always have the knowledge about the appropriate procedures to implement reverse logistics efficiently by choosing not to use it.

\section{REFERENCES}

ABRACERVA (2019) Associação Brasileira da Cerveja Artesanal. Available: $<$ https://abracerva.com.br/2019/06/07/brasil-chega-a-mil-fabricas-de-cerveja >. Acess: 7th June, 2019.

ADLMAIER, D.; SELLITTO, M. A. (2007) Embalagens retornáveis para transporte de bens manufaturados: um estudo de caso em logística reversa. Revista de Produção, v. 17, n. 2, p. 395-406.

AMBEV. Atitudes sustentáveis e economia. Available:

$<$ https://www.ambev.com.br/sustentabilidade/residuo-zero-e-clima/> Acess: 8th August, 2019.

ÁVILA, D. F.; GRIEBELER, M. P. D. (2013) Logística Reversa: um diferencial competitivo para as organizações. Revista de Administração. v. 11, n. 19, p. 65-82, Available: $<$ http://revistas.fw.uri.br/index.php/revistadeadm/article/view/955/1551>. Acess: 5th September, 2019.

BALLOU, R. H. (2006) Gerenciamento da cadeia de suprimentos: Logística Empresarial. 5.ed. Porto Alegre: Bookman.

BALLOU, R. H. (2006) Logística empresarial: transporte, administração de materiais e distribuição física. 5. ed. Porto Alegre: Bookman.

BOONE, L. E.; KURTZ, D. L. (2001) Contemporary marketing. Orlando: The Dryden 
Press.

BRASIL (2010) Política Nacional de Resíduos Sólidos. Lei n. 12.305, de 2 de agosto de 2010. Presidência da República, Departamento da Casa Civil. Brasília.

CATALLÃO, B.; FOGOLIN, M. H. (2011) Logística Reversa e Marketing Verde. Revista Científica do Unsalesiano. Lins, São Paulo. Ano 2, n.5. Available:

$<$ http://www.salesianolins.br/universitaria/artigos/no5/artigo84.pdf > . Acess: 29th August, 2019.

CHAVES, G. L. D.; BATALHA, M. O. (2006) Os consumidores valorizam a coleta de embalagens recicláveis? Um estudo de caso da logística reversa em uma rede de hipermercados. Gestão \& Produção. v.13, n.3, p.423-434.

CHEHEBE, J. R. B. (1998) Análise do ciclo de vida de produtos: ferramenta gerencial da ISO 14000. Rio de Janeiro: Qualitymark.

CHOPRA, S.; MEINDL, P. (2003) Gerenciamento da cadeia de suprimentos: Estratégia, Planejamento e Operação. São Paulo: Prentice Hall.

CHRISTOPHER, M. (2002) Logística e gerenciamento da cadeia de suprimentos. 3. ed. São Paulo: Pioneira.

CONSELHO DE PROFISSIONAIS DE GESTÃO DA CADEIA DE SUPRIMENTOS.

Glossary of Terms. Available: <http://www.cscmp.org/resources-research/glossary-terms> Acess: 22nd August, 2019.

CORRÊA, H. L.; CORRÊA, C. A. (2004) Administração de produção e operações. São Paulo: Atlas.

FELIPE, L. N. (2009) A Logística reversa como ferramenta de melhoria nos processos das indústrias de revestimentos cerâmicos da região de Criciúma-SC. UNESC.

Available: <http://200.18.15.60:8080/pergamumweb/vinculos/000041/00004123.pdf>. Acess: 5th September, 2019.

FESTIVAL de Cerveja Ilhabela. $\mathbf{2}^{\mathbf{0}}$ Festival da Cerveja Artesanal de Ilhabela. Available: $<$ https://festivaldecervejailhabela.com.br/> Acess: 21st August, 2019.

GUARNIERI, P. (2014) Vantagens com a Implementação da Logística Reversa. Site Apoio Ambiental. Notícia. Available:

<http://www.apoioambiental.com.br/noticia.aspx?id=MTEz>. Acess: 11th September, 2019

HANSEN, D.; MOWEN, M. (2001) Gestão de Custos: Contabilidade e Controle, São Paulo: Thomson Learning.

LACERDA, L. (2000) Logística reversa: uma visão sobre os conceitos básicos e as práticas operacionais. Tecnologística, São Paulo, v. 74, n. 6, p. 47-51. Available:

$<$ http://www.tecnologistica.com.br/tipo_revista/ceagesp-busca-parceiros-para-projeto-debanco-de-caixas/>. Acess: 21st August, 2019.

LACERDA, L. (2002) Logística reversa: uma visão sobre os conceitos básicos e as práticas operacionais. Centro de Estudos em Logística, COPPEAD, UFRJ. Available:

$<$ https://docplayer.com.br/4272537-Logistica-reversa-uma-visao-sobre-os-conceitos-basicose-as-praticas-operacionais.html> Acess: 29th July, 2019.

LACERDA, L. (2009) Logística reversa: uma visão sobre os conceitos básicos e as práticas operacionais. Available:

$<$ http://www.paulorodrigues.pro.br/arquivos/Logistica_Reversa_LGC.pdf > . Acess: 11th September, 2019. 
DOI: 10.14807/ijmp.v11i5.1298

LEITE, P. R. (2003) Logística reversa: meio ambiente e competitividade. São Paulo: Prentice Hall.

LEITE, P. R. (2002) Logística Reversa: nova área da logística empresarial. Tecnologística, São Paulo, v. 78, n. 8, p. 102-104, Available:

$<$ https://www.tecnologistica.com.br/portal/revista/edicao-anterior/78/>. Acess: 30th July, 2019.

LEITE, P. R. (2009) Pesquisa mostra evolução da Logística Reversa no país. Tecnologística, ano XIV, n.162, p. 30-36.

LIVA, P. B. G; PONTELO, V. S. L.; OLIVEIRA, W. S. (2003) Logística Reversa. Gestão e Tecnologia Industrial. IETEC.

MESQUITA, R. A. C. (2000) Sistemas ERP (Enterprise Resource Planning), Centro Universitário de Brasília - UNICEUB.

MUELLER, C. F. (2005) Logística reversa meio-ambiente e produtividade. Estudos realizados - GELOG-UFSC. Available: <http://limpezapublica.com.br/textos/artigo01_1.pdf> Acess: 5th August, 2019

NOVAES, A. (2015) Logística e gerenciamento da cadeia de distribuição. 4. ed. Rio de Janeiro: Elsevier.

RAZZOLINI FILHO, E.; BERTÉ, R. (2009) O reverso da logística e as questões ambientais no Brasil. Curitiba: Ibpex.

ROCHA, J.; SELIG, P. (2002) O Sistema de Gestão Balanced Scorecard e seus Impactos sobre a Teoria de Custos. Comunicação apresentada no VII Congreso del Instituto Internacional de Costos, Julio, León. Available:

$<$ http://intercostos.org/documentos/congreso-07/Trabajo016.pdf> Acess: 5th September, 2019.

SÃO PAULO Secretaria do Meio Ambiente. (2014) Logística reversa. Texto Flávio de Miranda Ribeiro. São Paulo: SMA.

SIMCHI LEVI, D.; KAMINSKY, P.; SIMCHI LEVI, E. (2010) Cadeia de suprimentos projeto e gestão: conceitos, estratégias e estudos de caso. Porto Alegre: Bookman.

SLACK, N. (1997) Administração da produção; São Paulo: Atlas.

STEVEN, M. (2004) Networks in reverse logistics. DYCKHOFF, H.; LACKES, R.; REESE, J. Supply chain management and reverse logistics. Berlim: Springer.

STOCK, J. R. (1998) Reverse logistics programs. Illinois: Council of Logistics Management.

SUA PESQUISA (2015) Logística Reversa: o que é, vantagens para o meio ambiente, exemplo, logística reversa e sustentabilidade, conceito. Available:

$<$ http://www.suapesquisa.com/ecologiasaude/logistica_reversa.htm>. Acess: 11th September, 2019. 